\title{
EDUCAÇÃO INCLUSIVA: PRINCÍPIOS E REPRESENTAÇÃO
}

ERRATA

\section{PÁGINA 97}

\section{Retirar os textos:}

no $3^{\circ}$ PRINCÍPIO

Apresento anexo um Quadro das Necessidades Educacionais Especiais

no $5^{\circ}$ PRINCÍPIO

e apresento anexo um modelo de Ficha de Avaliação das Necessidades Educacionais Especiais

$* * * * * * * * * * * * * * * * * * * * * * * * * * * * * * * * * * * * * * * * * * * * * * * * * * * * * * * * * * * * * * * * * * * * * * * * *$

\section{PÁGINA 308}

Junho de 2007

***********************************************************************************

PÁGINAS 315-316-328: consta o nome da escola. Gostaria que não fosse citado no dia da defesa.

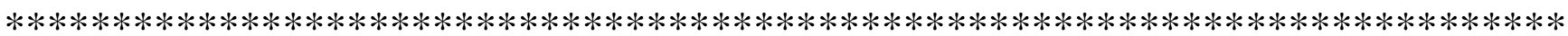

\section{PÁGINA 327}

\section{$8^{\circ}$ A INTER-RELAÇÃO ESCOLA X FAMÍLIA X COMUNIDADE:}

* numa realidade em que 30\% das mulheres são responsáveis pela família

*muitas mães não sabem ler

$* * * * * * * * * * * * * * * * * * * * * * * * * * * * * * * * * * * * * * * * * * * * * * * * * * * * * * * * * * * * * * * * * * * * * * * * * * * * * *$

\section{PÁGINA 354}

A expressão "você considera" está repetida.

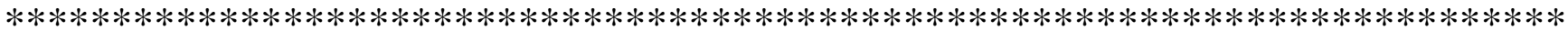

As páginas 97 e 327 seguem abaixo, com as alterações, para substituição. 
permanecem em sua cultura excludente para o reconhecimento e aceitação das pessoas como são e o impulso de, nesse espaço, ter a oportunidade de se desenvolver.

$2^{\circ}$ PRINCÍPIO - ACESSIBILIDADE - exponho as bases legais e situacionais da acessibilidade física e instrumental, essenciais no atendimento das crianças com deficiência física ou sensorial; comunicacional, abrangendo os processos interacionais da professora com seus alunos e alunas, atitudinal, referente à representação da diferença em suas variadas manifestações para os profissionais da escola e curricular, referente aos ajustes necessários nas ações didáticas para tornar a aula acessível a todas as crianças, inclusive aquelas com deficiências.

$3^{\circ}$ PRINCÍPIO - CURRÍCULO MULTICULTURAL CRÍTICO - nesse princípio pretendo esclarecer a necessidade de tornar crítico um currículo uniforme e seqüencial, herdado da educação tradicional; e multicultural, para abranger toda a diversidade do povo brasileiro em sua identidade e manifestação cultural. Apresento aos que tiverem a pretensão de fortalecer a escola enquanto espaço de resistência à desigualdade social de pessoas com capacidade, etnia e gênero diferentes, algumas reflexões e diretrizes: Por uma escola que valorize a diferença; Por uma identidade multicultural e Por uma educação nãosexista.

$4^{\circ}$ PRINCÍPIO - POR UMA OUTRA PEDAGOGIA - aqui exponho a necessidade de implantação de uma gestão da classe direcionada à diversidade das crianças, por meio da organização do grupo-classe, que inclui a gestão da turma e a diversificação das atividades. Além disso, mostro a importância do aluno conhecer sua própria história e aprender a valorizar seu passado e as pessoas das quais é descendente; aprender que é capaz de aprender, construindo um autoconceito positivo; por fim aponto que as crianças precisam, com urgência, participar do ensino colaborativo, tendo a oportunidade de experimentar diferentes formas de apoio e ajuda mútua.

$5^{\circ}$ PRINCÍPIO - AVALIAÇÃO FORMATIVA - mostro a importância da observação do professor em todo o processo de aprendizagem do aluno para compreender a maneira como aprende, o que já sabe e o que resta a aprender, desafiando-o para isso e discuto a questão da promoção e certificação dos alunos com deficiência. 
criativo, colabora na evolução de um grupo mais amplo de crianças, incluindo-as na sala de aula na condição de aprendizes, que contribui com sua ação para a necessária crescente justiça social almejada, é um desafio que justifica todos os esforços. A questão que incomodava as professoras e que deixo como proposta de reflexão: Como efetivar a formação de professores, de maneira reflexiva e crítica, no coletivo da escola?

$7^{\circ}$ Gestão Participativa: As ações de um dirigente bem intencionado foram descritas na sua busca de organização do espaço físico da escola que ampliou as oportunidades de acesso dos alunos ao conhecimento, promoveu o enriquecimento curricular pela participação das crianças semanalmente nas Salas de Vídeo, Leitura e Informática, pela reforma que deixou a escola mais bonita e ainda pela apresentação do seu plano pedagógico. Foi enfocada a importância da participação de cada uma das pessoas da equipe escolar e os empecilhos que encontram na resistência e omissão de alguns e na diretividade da administração escolar em algumas situações. Fica uma questão direcionada a toda a equipe escolar: Como efetivar a participação de cada uma das pessoas da equipe escolar, aproveitando todos os recursos materiais e humanos na gestão da escola para obter a finalidade de sua existência, o desenvolvimento de cada uma das crianças, com base em suas diferentes possibilidades e condições de aprendizagem?

$8^{\circ} \underline{A}$ inter-relação escola $\mathrm{x}$ família $\mathrm{x}$ comunidade: os educadores esperam que os pais sejam informados, estimuladores da aprendizagem e participantes da vida escolar das crianças. A realidade não é bem essa. Alguns pais não orientam suas crianças, outros estimulam que faltem às aulas para buscar dinheiro nas ruas e na feira, outros ainda são negligentes com sua saúde ou até os maltratam. A expectativa dos educadores que buscam um padrão familiar normal, de um casal que cuida de suas crianças, é completamente inadequada numa realidade em que 30\% das mulheres são responsáveis pela família; as crianças sofrem em meio ao turbilhão emocional familiar, seja pela agressão paterna, seja pela interpretação da separação, seja pela ausência da mãe. As professoras têm expectativa de que os recursos culturais e a competência educativa sejam mobilizadas pela presença das crianças na escola, mas não encontra eco nas famílias em que muitas mães não sabem ler, na periferia da cidade de São Paulo, em pleno século XXI. Não é possível que se analise um fenômeno por um dos seus aspectos. A realidade escolar traz tensões para as crianças que pedem ajuda de suas professoras para ajudá-las a ler, a escrever com letra de mão e a fazer contas. A questão mais importante talvez seja: Como conhecer a realidade das famílias e apoiá-las na responsabilidade de educar as crianças? 